\title{
54 路面特性係数測定装置の試作について
}

\author{
成定康平・官下正義
}

(松下電器産業(侏) 照明研究所)

1. 路面はその光学的特性を平均輝度係数 $q_{0}$ と鏡面係数のの二つの係数で分類でるる

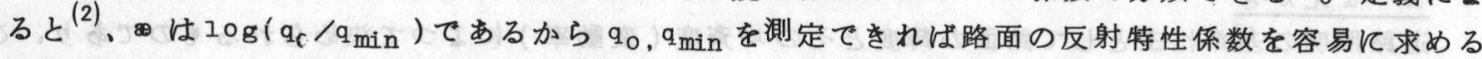
ことができる。今回現場て簡便敏速に路面の反射特性係数を求めるととのでさる装置を開発し、実用 化したのてその概要を報告する。

2. 構造の概要を为 1 図に示す。Pは測定点、LM は輝度計 1! は表面鏡、 $\mathrm{L}_{1} 、 \mathrm{~L}_{2}$ は照明用光源であつて、Gは後述の特殊 なグリッド、○は拡散板である。

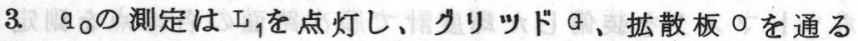
光て $P$ 点を各方向から均一な光度の光で照明し、 $P$ 点の輝度 と照度との比を測定して求める。グリッド aは为 2 図に示す

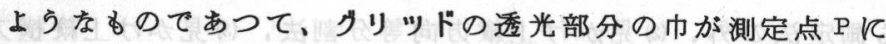
対するグリッド各部の鉛直角 $r の$ 余弦飞逆比例させてあるの て、クリッド各部より P 点に向ら光度屿等しくなる。

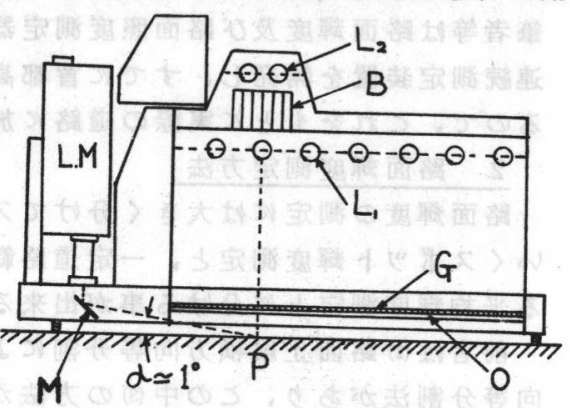

为 1 図 測定装置概要

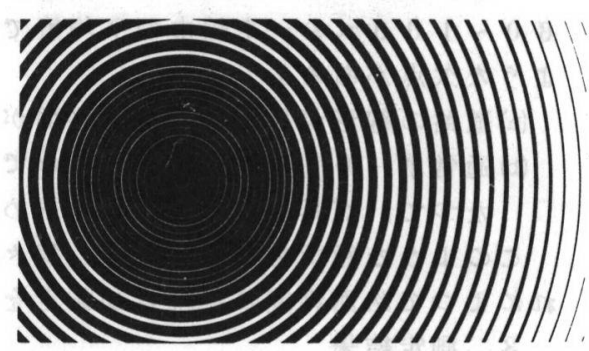

为 2 図グリッド 拡散板 ○を取除を、ルーバBを通る光源 $\mathrm{L}_{2}$ の光による $\mathrm{P}$ 点 の輝度と照度を測定する。

5. 実際には ム 、 $\check{2}_{2}$ を安定状態にし、適当な值に較正す るとその都度照度を測定しなくとも輝度の值から直接 $q_{0}$ 、 $\mathrm{q}_{\min }$ を読みとるととがでをる。

6. 装置は昼夜に関係なく使用でさる上5下部に暗幕のス カートを設けるとともに、移動を容易に行なえるよら車輪を 備え、測定に際してはハンドルに上つて車輪をいつせいに引 を上げる機構をるつている。

7. 精密に輝度係数分布を測定して得られた值とこの装置 を用いて測定した值とは良く一致した。

8. 本装置を用いて首都高速道路、東名高速道路、その他 一般道路の一部で測定を実施したが、良好な動作状態を示し、照明設計に充分実用し得ることが明ら かになつた。なお、とれらの測定結果から我国における使用中の一般路面の反射特性係数は、大部分 $\circledast=0.04 \sim 0.08$ 、 $=0.3 \sim 0.7$ の範囲に入るととが明らかとなつた。 参考文献

(1) 成定 昭和 43 年電気四学会連合大会予稿 $\quad S 4-38$ 頁 (1967)

(2) J. B. de Boer, J. Vermeulen, CIE, Washington ( 1967 )

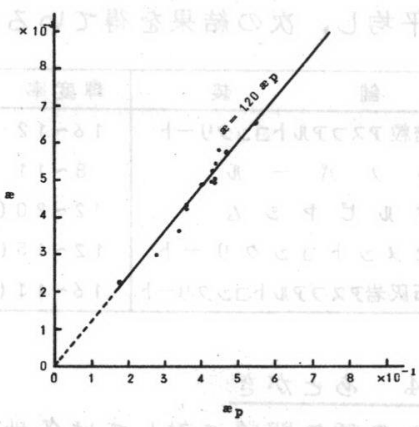

为 3 図. 古 $\boldsymbol{D}_{\mathrm{p}}$ の関係 